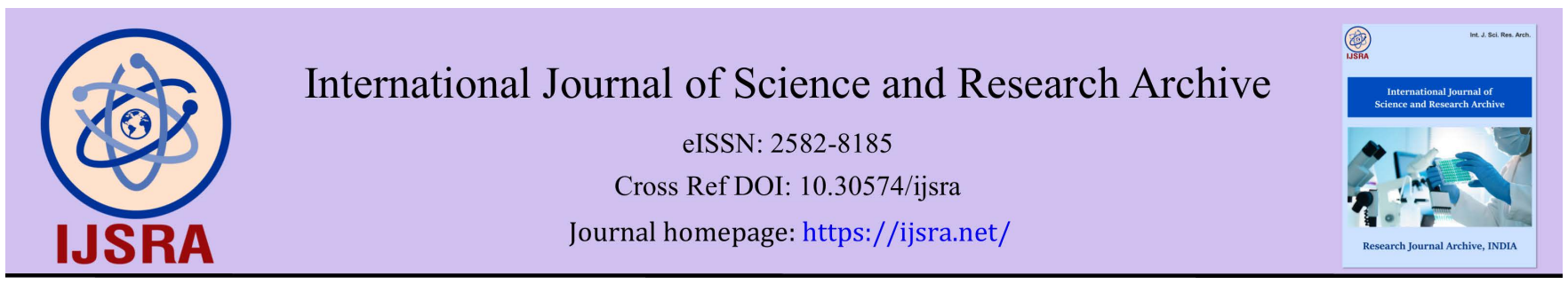

(RESEARCH ARTicle)

\title{
Relation between fresh biomass of plant species (Senecio L.) and elevation in Shan County
}

\author{
Bing-Hua Liao 1, 2, \\ 1 Henan Province Key Laboratory of Germplasm Innovation and Utilization of Eco-economic Wood Plant, the Vital \\ Laboratory of Ecological Restoration in Hilly Areas, The Key Laboratory of Ecological Restoration in Hilly Areas, Institute \\ of chemistry and environmental engineering, Ping-ding-shan University, Ping-ding-shan City, 467000, China. \\ 2 Institute of life and science, Henan University, Kai-feng City, He-nan Province, 475004, China.
}

International Journal of Science and Research Archive, 2021, 04(01), 129-135

Publication history: Received on 23 October 2021; revised on 29 November 2021; accepted on 01 December 2021

Article DOI: https://doi.org/10.30574/ijsra.2021.4.1.0188

\begin{abstract}
A key plant species (Senecio L.) not only is a vital multilevel functional medicinal material of indications of respiratory tract infections, tonsillitis, pharyngitis, pneumonia, conjunctivitis, enteritis, dysentery, but also it is a widely distributed wide plant species. This plant species is widely distributed elevation from $500 \mathrm{~m}$ to $1500 \mathrm{~m}$ in six landscapes and vegetation ecosystems in Shan County of China. However, understanding dynamics of dry biomass of this species is difficult along elevation. This research explained that the relation between fresh biomass of the species and elevation is a significant positive connection from $500 \mathrm{~m}$ to $1000 \mathrm{~m}(P<0.01)$ as well as the links between fresh biomass of this species and elevation is a significant negative connection from $1000 \mathrm{~m}$ to $1500 \mathrm{~m}(P<0.01)$. This study provides six ecosystem types and a series of areas ecological adaptation for finding new medicinal species. Therefore, this study has vital theoretical and practical significance for medicinal plant protection along different elevation and environmental gradient over the spatial-temporal-environmental-disturbance scales (STEDS) in the multilevel green space diversity.
\end{abstract}

Keywords: Fresh biomass; Elevation; Connection; Areas ecological adaptation; Plant medicinal species

\section{Introduction}

Natural environmental and plantation factors often integrated effects of the human activities and acid rain on medicinal plant species by the research of process for deposition of thin films ${ }^{1-3}$. But medicinal plant functional more traits may be finding through key physiological characters of antireflection coatings and ecological functional traits along elevation gradient $^{4-7}$. Using plant leaf oxide films technological tools ${ }^{8-10}$, scientists explain that multilevel functional traits of medical species ${ }^{11,12}$ and medical plant communities ${ }^{13,14}$ by dynamic framework model ${ }^{15}$ for food chains ${ }^{16}$.

For instance, dynamics of community's height ${ }^{17}$, tree community's total trunk volume ${ }^{18}$, plant community's tree individual number ${ }^{19}$, plant individual specie's and plant communities' crown volume ${ }^{20,21}$ of medicinal plant (Sophora japonica) along elevation. Although limits to local agricultural landscape area for protecting more natural landscapes ${ }^{22}$ (e.g., grasslands, wetlands, water and forests) or some half natural landscapes (e.g., green ecological urban and beautiful green countryside) areas for sustainable medical plant species, but dynamics of total dry biomass ${ }^{23}$, total fresh biomass $^{24}$, vegetation coverage ${ }^{25}$, plant average height ${ }^{26}$, roots cuticle biomass ${ }^{27}$, leaf -stalk biomass ${ }^{28}$, stems cuticle biomass $^{29}$, species pair's co-dominance abundance dominancy ${ }^{30}$, Important Value ${ }^{31}$ and moisture content ${ }^{32}$ of (Cremastra Appendiculata) also deeply research.

\footnotetext{
* Corresponding author: Bing-Hua Liao

Institute of life and science, Henan University, Kai-feng City, He-nan Province, 475004, China.

Copyright $(2021$ Author(s) retain the copyright of this article. This article is published under the terms of the Creative Commons Attribution Liscense 4.0.
} 
Therefore, it is a vital topic issues that the relationship between gene level and medical plant roots cuticle functional traits $^{33,34}$, as well as the dynamics of roots cuticle biomass ${ }^{35}$, fresh roots biomass ${ }^{36}$, stems cuticle biomass ${ }^{37}$ associations with daily solar radiation for human cognitive ${ }^{38}$ medical plant ${ }^{39}$, especially, risk assessment and early warning mechanism (e.g., watersheds areas) ${ }^{40,41}$. In short, herein explains that relation between fresh biomass of this plant and elevation.

\section{Typical environmental condition, situation of typical vegetation and methods of research}

Study area is local in three typical zones: firstly, evergreen vegetation of north subtropical zone; secondly, evergreen and deciduous coniferous and broad-leaved mixed forest of north subtropical and warm temperate transition; thirdly, deciduous vegetation of warm temperate zone in Earth. Thus, this area is local in evergreen and deciduous coniferous and broad-leaved mixed forest in north subtropical and warm temperate transition in Shan County of China at STEDS (Figure 1).

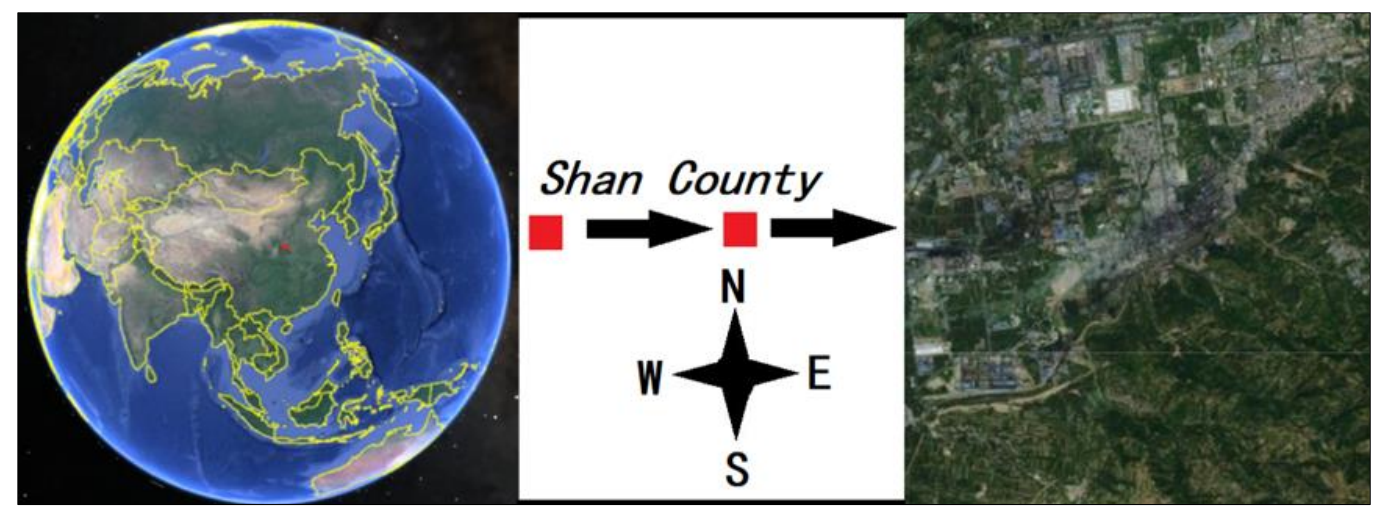

Figure 1 A Digital Cadaster Map of Typical Location in Shan County of China on Earth

There are long-time investigation of connections among dry biomass of medicinal plant species and elevation from 2005 to 2019. Investigation of "big data" included that dry biomass of medicinal plant species or other ecological index of medicinal plant species along the different elevation and environmental gradient by the previous key research over STEDS 42,43 .

Thus, there is relation between fresh biomass of (Senecio L.) and elevation, as well as there is a series of best six landscapes areas ecological adaptation of dry biomass of this plant species by the "big data" of the ecological investigation, qualitative analysis, and quantitative statistics, human cognitive ecological linguistic rules, scientific theories and ecological planning methods.

\section{Results and discussion}

Based on "big data" of plant investigation, this species is a widely distributed wide species along elevation from $500 \mathrm{~m}$ to $1500 \mathrm{~m}$. A key species (Senecio L.) is a widely distributed along the different elevation from $500 \mathrm{~m}$ to $1500 \mathrm{~m}$ in Shan County of China. However, understanding the elevation effect on the relation between fresh biomass of this plant species and elevation is very difficult, because elevation effect on plant root biomass ${ }^{43}$, bryophyte and lichen biomass ${ }^{44}$, wood biomass ${ }^{45}$, mushroom biomass and diversity biomass ${ }^{46}$, production of medicinal plant species ${ }^{47}$.

Using the dynamics of "big data" investigation, this work suggested there are five rules:

Firstly, herein showed that it is not only the increasing of fresh biomass of (Senecio L.) with the increasing of elevation from $500 \mathrm{~m}$ to $1000 \mathrm{~m}$, as well as there are but also decreasing of fresh biomass of (Senecio L.) with increasing of elevation from $1000 \mathrm{~m}$ to $1500 \mathrm{~m}$ (Figure 3).

Secondly, this study explained that there is the significant positive connection between fresh biomass of (Senecio L.) and elevation from $500 \mathrm{~m}$ to $1000 \mathrm{~m}(P<0.01)$, as well as there is the significant negative connection between fresh biomass of (Senecio L.) and elevation from $1000 \mathrm{~m}$ to $1500 \mathrm{~m}$ in Shan County of Henan Province of China at spatiotemporal scale $(P<0.01)$ (Table 2). 
Thirdly, this research shows a good areas ecological adaptation of (Senecio L.) from 500m to 1500 in Shan County of China. Because there are results that there are not only dynamics of different air environmental factors, there are but also dynamics of different environmental factors from $500 \mathrm{~m}$ to $1500 \mathrm{~m}$ by the dynamics of fresh biomass of this medical species (Figure 1,2).

Table 1 Fresh Biomass of this Medical Plant Species Association with Elevation Gradient

\begin{tabular}{|l|c|}
\hline Fresh Biomass along Elevation & Fresh Biomass of This Medical Plant Species \\
\hline Elevation From 500 to 1000 & $0.994^{* *}$ \\
\hline Elevation From 1000 to 1500 & \\
\hline
\end{tabular}

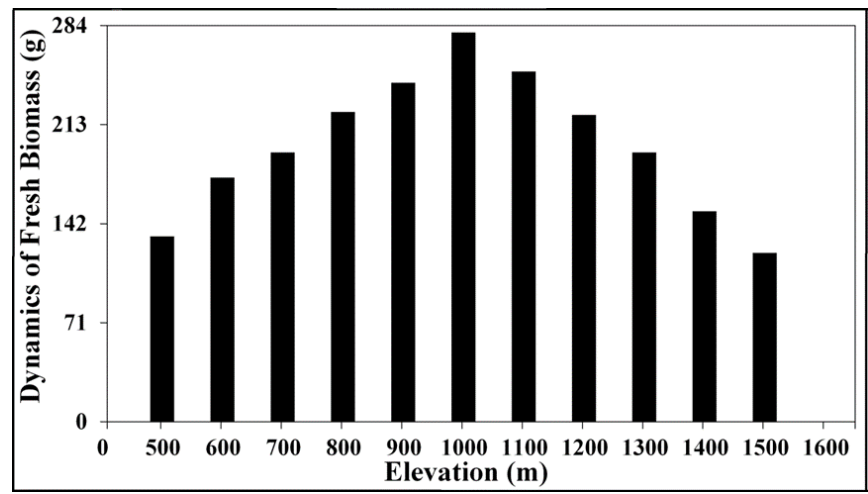

Figure 2 Dynamics of Fresh Biomass of (Senecio L.) along Elevation Gradient

Fourthly, this research proposed that the medicinal plant species (Senecio L.) is local in the six typical ecosystem types (forests ecosystem, mixed ecosystem between forestation and grassland, mixed ecosystem between forests and wetland, mixed ecosystem between forests and river, mixed ecosystem between forests and eco-urban, mixed ecosystem between forests and rural settlement) by the "big data" of fresh biomass of medicinal plant species investing along elevation, because there may be results that there are not only dynamics of air environments, there are but also dynamics of soil environmental factors from $500 \mathrm{~m}$ to $1500 \mathrm{~m}$ along elevation gradient.

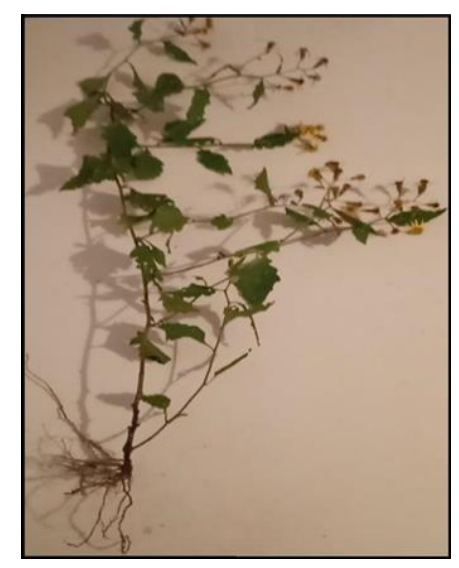

Figure 3 Total Structures of Medical Plant Species (Senecio L.) by Long-time Investigation

Fifthly, the typical medical plant species (Senecio L.) not only is a vital functional medicinal material of indications of treating to respiratory tract infections, tonsillitis, pharyngitis, pneumonia, conjunctivitis, dysentery and enteritis, but also it is belonging to Compositae families of Senecio races of Discotyledoneae in Angiospermae, especially, total structures of (Senecio L.) (Figure 3).

Thus, this research found a series of typical areas ecological adaptation of plant (Senecio L.) of indication of treating respiratory tract infections, tonsillitis, pharyngitis, pneumonia, conjunctivitis, enteritis, dysentery along elevation gradient, as well as there is a relation between fresh biomass of this typical medical plant species (Senecio L.) and elevation gradient in Shan County of China. 


\section{Discussion}

The respiratory tract infections, tonsillitis, pharyngitis, pneumonia, conjunctivitis, dysentery and enteritis always influence public health, which often led human died. But understanding dynamics of medicinal plant species is very difficult issues, for instance, molecular dynamics ${ }^{48}$, evolutionary dynamics ${ }^{49}$ and indigenous medical plant ${ }^{50}$. So, finding a vital multilevel functional medicinal plant (Senecio L.) of indications of respiratory tract infections, tonsillitis, pharyngitis, pneumonia, conjunctivitis, enteritis and dysentery not only is a key value plant species, but also treating many people's diseases or saving some individual human-lived. As such, it is a research that (Senecio L.) were found from 500m to $1500 \mathrm{~m}$ in Shan County of Henan Province of China. And this research suggested three rules between fresh biomass of (Senecio L.) and elevation gradient over STEDS:

- This work showed that there is an increasing of fresh biomass of (Senecio L.) with enhancing of elevation from $500 \mathrm{~m}$ to $1000 \mathrm{~m}$, as well as there is decreasing of fresh biomass of (Senecio L.) with increasing of elevation from $1000 \mathrm{~m}$ to $1500 \mathrm{~m}$ (Figure 2). There is the significant positive connection between fresh biomass of (Senecio L.) and elevation from $500 \mathrm{~m}$ to $1000 \mathrm{~m}(P<0.01)$ as well as there is the significant negative connection between fresh biomass of (Senecio L.) and elevation from $1000 \mathrm{~m}$ to $1500 \mathrm{~m}$ along elevation gradient in Shan County $(P<0.01)$ (Table 1$)$.

- This research provides six lands types (forests vegetation, mixed vegetation between forests and grassland, mixed vegetation between forests and wetland, mixed vegetation between forests and river, mixed vegetation between forest and eco-urban, mixed vegetation between forests and green beatified countryside), as well as there is a series of eco-adaptation of landscape areas (for instance, the best areas ecological adaptation of (Senecio L.) from $500 \mathrm{~m}$ to $1500 \mathrm{~m}$ ) for finding this plant (Senecio L.) by dynamics of fresh biomass (Senecio L.) along elevation gradient.

- (Senecio L.) not only is a vital multilevel functional medicinal material of indications of treating to respiratory tract infections, tonsillitis, pharyngitis, pneumonia, conjunctivitis, dysentery and enteritis, but also it is belonging to Compositae families of Senecio races of Discotyledoneae in Angiospermae, as well as it is widely distributed wide specie by the "big data" investigation of fresh biomass of (Smilax scobinicaulis) in Shan County of Henan Province (Figure 1, 2, 3).

Indeed, better regional regulators and local government need better planning and regulation many medicinal plant species sustainability ${ }^{51}$ of ecosystems by researches on the vital biomass of medicinal plants ${ }^{52}$ along elevation and environments with dynamics of plant diversity in the global, regional and landscapes natural ecosystem types with the ways "big data" investigation, scientific quantitative statistics ${ }^{53}$ by landscape stability and sustainable medical plant diversity production ${ }^{54}$

\section{Conclusion}

This research has a vital theoretical and practical significance for the reasonable protection of (Senecio L.) along elevation gradient, because this plant species not only is an important widely distributed wide medicinal material pant by treating infections, tonsillitis, pharyngitis, pneumonia, conjunctivitis, enteritis, dysentery, but also there are five rules by relation between fresh biomass of (Senecio L.) and elevation. Government planner will protects landscape habitats of this medical plant species (Senecio L.) by new eco-restoration of multilevel diversity technology ${ }^{55}$ in the future.

\section{Compliance with ethical standards}

\section{Acknowledgments}

This work was supported by A Grade of Key Disciplines of Environmental Science Foundation, B Grade of Key Disciplines of Mistrials Science of Ping-Ding-shan University in China; Science and Technology Department of He'nan Province Foundation (KJT-17202310242; 092102110165); Subprojects by Intergovernmental Platform on Biodiversity and Ecosystem Services (IPBES); and better ideas of researchers of "1st Biotechnology World Congress" in 2011, "2st Biotechnology World Congress" in 2012, "3st Biotechnology World Congress” in 2013 is appreciated.

\section{References}

[1] Liao BH, Liu HY, Lu SQ, Wang KF, Probst A, Probst JL.Combined toxic effects of cadmium and acid rain on Vicia faba L. Bulletin of Environmental Contamination and Toxicology. Nov 2003; 71(5): 998-1004. 
[2] Liao BH, Liu HY, Zeng QR, Yu PZ, Probst A, Probst JL. Complex toxic effects of Cd2+, Zn2+, and acid rain on growth of kidney bean (Phaseolus vulgaris L). Environment International. Aug 2005; 31(6): 891-95.

[3] Liao BH, Liu MC, Lee CC. Process for deposition of AlF3 thin films. Applied Optics. May 2008; 47(13): 41-45.

[4] Liao BH, Wang XH. Plant functional group classifications and a generalized hierarchical framework of plant functional traits, African Journal of Biotechnology. Dec 2010; 9(54): 9208-13.

[5] Liao BH, Lee CC. Antireflection coatings for deep ultraviolet optics deposited by magnetron sputtering from Al targets. Optics Express. Apr 2011; 19(8): 7507-12.

[6] Liao BH, Ding SY, Guo-Fu Liang GF, Guo YL, Tian L, Shu S, Zhang Y, Hu HX. Dynamics of plant functional groups composition along environmental gradients in the typical area of Yi-Luo River watershed. African Journal of Biotechnology. Oct 2011; 10(65): 14485-92.

[7] Liao BH, Ding SY, Hu N, Gu YF, Lu XL, Liang GF, Liu J, Fan YL, Zhai YJ, Ding SP, Ding S. Dynamics of environmental gradients on plant functional groups composition on the northern slope of the Fu-Niu Mountain Nature Reserve. African Journal of Biotechnology. Dec 2011; 10(82): 18939-47.

[8] Liao BH, Kuo CC, Chen PJ, Lee CC. Fluorine-doped tin oxide films grown by pulsed direct current magnetron sputtering with a Sn target. Applied Optics. Mar 2011; 50(9): 106-10.

[9] Liao BH, Hsiao CN. Improving optical properties of silicon nitride films to be applied in the middle infrared optics by a combined high-power impulse/unbalanced magnetron sputtering deposition technique. Applied Optics. Feb 2014; 53(4): 377-82.

[10] Liao BH, Chan SH, Lee CC, Kuo CC, Chen SH, Chiang D.FTO films deposited in transition and oxide modes by magnetron sputtering using tin metal target. Applied Optics. Feb 2014; 53(4): 148-53.

[11] Liao BH, Liu QF, Lu D, Cao XL, Lei ZL, Si XX, Guo XN, Huang BX, Zhang WW, Wen F, Niu J, Zhu W, Wang RJ, Li JJ, Dong H, Zhang C, Li ZK, Chu HX, Chai JY, Chen ZH, Wang ZC, Li-Sha Ma LS, Qiu BB, Li CP, Hong Y, Yin CC, Qiao XP, Chen JM, Wang SW, Miao HH, Li WL, Meng N, Ye HL, Yang ML, Liu GH, Chen XM, Xu L, Tu CL, Guan YW, Dong JH, Pan WJ, Dong CX, Wang P, Xiao XY, Wang Z, Ma JJ, Ruan HB, Zhang ZZ, Zhang J, Tian YL, Ning Y, Liu Y, Gao YH, Zhou QP, Sheng ZF, Yu HL, Huang BH, Yuan XQ, Cheng Z, Yang MF, Xu Y. Dynamics of environmental gradients on plant functional groups composition species in near-natural community ecological restoration on the southern slope of the Fu-Niu Mountain Nature Reserve. Journal of Science. Jun 2014; 4(5): 306-12.

[12] Liao B, Ying ZX, Hiebeler DE, Wang YQ, Takada T, Nijs I. Species extinction thresholds in the face of spatially correlated periodic disturbance. Scientific Reports. Oct 2015; 5(1): 15455.

[13] Liao B, Boeck, HJD. Li ZQ, Nijs I. Gap formation following climatic events in spatially structured plant communities. Scientific Reports. Jun 2015; 5(1): 11721.

[14] Liao B, Bogaert J, Nijs I. Species interactions determine the spatial mortality patterns emerging in plant communities after extreme events. Scientific Reports. Jun 2015; 5(1): 11229.

[15] Liao BH. A new model of dynamic of plant diversity in changing farmlands, implications for the management of plant biodiversity along differential environmental gradient in the spring. African Journal of Environmental Science and Technology. Mar 2014; 8(3): 171- 77.

[16] Liao B, Chen JH, Ying ZX, Hiebeler DE, Nijs I. An extended patch-dynamic framework for food chains in fragmented landscapes. Scientific Reports. Sep 2016; 6(1): 33100.

[17] Liao BH, Liu YP, Zuo H, Xu YL, Xia JR, Zhang XG, Jiang CG, Song CJ, Yu ZY. Elevation Dynamics of (Sophora japonica) Community's Height in Ye County. International Journal of Research Pharmaceutical and Nano Sciences. Feb 2019; 8(1): 48- 54.

[18] Liao BH, Liu YP, Zuo H, Kong YY, Xia JR, Song CJ, Yu ZY, Zhang XG, Jiang CG, Xu YL.. Dynamics of 18 (Sophora japonica) Tree Community's Total Trunk Volume along Elevation Gradient in Ye County. International Journal of Current Advanced Research. Jun 2019; 8(6): 19063-66.

[19] Liao BH, Liu M, Huang CZ, Zhang QX, Chang Z, Wang S, Wang XM, Liu QX, Zhang JG, Liu YX. Dynamics of (Sophora japonica) Community's Tree Individual Number along Elevation Gradient in Ye County. International Journal of Pharmacognosy and Pharmaceutical Sciences. Feb 2019; 1(2): 1-4.

[20] Liao BH, Liu YP, Zuo H, Xu YL, Xia JR, Zhang XG, Jiang CG, Song CJ, Yu ZY. Dynamics of 18 (Sophora japonica) Tree Individual Specie's Crown Volume along Elevation Gradient in Ye County. International Journal of Research Pharmaceutical and Nano Sciences. Feb 2019; 8(1): 62-68. 
[21] Liao BH, Liu YP, Zuo H, Xia JR, Yu ZY, Song CJ, Zhang XG, Jiang CG, Xu YL. Dynamics Crown Volume of 18 (Sophora japonica) Tree Communities along Elevation Gradient in Ye County. Open Journal of Ecology. Jul 2019; 9(7): 20915.

[22] Liao AU, Georgina MM, Ekins P. Limits to agricultural land for retaining acceptable levels of local biodiversity. Nature Sustainability. Jun 2019; 2(6): 491-98.

[23] Liao BH. Links between Dry Weight Biomass of (Cremastra Appendiculata) of Biomedical and Pharmaceutical Plant and Elevations by Long-time Investigation of "Big Data". World Journal of Pharmaceutical Research. Oct 2020; 9(14): 14-24.

[24] Liao BH. Links between Total Biomass of Fresh Weight of (Cremastra Appendiculata) and Elevation in Biomedical and Pharmaceutical Plant Science by Long-time Investigation of "Big Data". European Journal of Biomedical and Pharmaceutical sciences. Oct 2020; 7(11): 83-88.

[25] Liao BH. Links between Vegetation Coverage of (Cremastra Appendiculata) and Elevation in Biomedical and Pharmaceutical Plant Science by "Big Data" of Long-time Investigation. World Journal of Pharmaceutical Research. Nov 2020; 9(15): 72-82.

[26] Liao BH. Relation between plant average height of (Cremastra appendiculata) and elevations. GSC Advanced Research and Reviews. Nov 2020; 5(2): 104-10.

[27] Liao BH. Links between Biomass of (Cremastra appendiculata) Roots Cuticle and Elevation along Elevation Gradient by Big Data of long-time wild investigation in Mei County. International Journal of Applied Science. Nov 2020; 3(11): 1-7.

[28] Liao BH. Links between Leafstalk Biomass of (Cremastra appendiculata) and Elevation by Big Data of Long-time Wild Investigation in Mei County. Journal of Drug Delivery and Therapeutics. Dec 2020; 10(6): 55-60.

[29] Liao BH. Links between Biomass of (Cremastra Appendiculata) Stems Cuticle and Elevation by Big Data of Longtime Wild Investigation in Mei County. Sumerianz Journal of Agriculture and Veterinary. Dec 2020; 3(12): 17882 .

[30] Liao BH. Links between Species Pair's Co-dominance Abundance Dominancy of (Cremastra Appendiculata) of Biomedical and Pharmaceutical Plant and Elevations. European Journal of Biomedical and Pharmaceutical sciences. Nov 2020; 7(12): 54-59.

[31] Liao BH. Links between Important Values of (Cremastra appendiculata) and elevations by long-time investigation and qualitative analysis and quantitative statistics of "Big data". International Journal of Science and Research Archive. Dec 2020; 1(2): 44-50.

[32] Liao BH. Links between moisture content of biomass of (Cremastra Appendictlata) and elevations by long-time investigation and qualitative analysis and quantitative statistics of "Big data". Journal of Biological Innovation. Jan 2021; $10(1): 208-16$.

[33] Liao BH, Xu ZL, Gao F, Zhang SH, Liang RJ, Dong SH. The relationship between HSP60 gene polymorphisms and susceptibility to atherosclerosis. European Review for Medical and Pharmacological Sciences. Mar 2020; 24(5): 2667-73.

[34] Liao BH. Links between Biomass of (Cremastra Appendiculata) Roots Cuticle and Daily Solar Radiation by Big Data of Long-Time Wild Investigation in Mei County. EAS Journal of Pharmacy and Pharmacology. Dec $2020 ; 2$ (6): 205-10.

[35] Liao BH. Linkages between Biomass of (Smilax scobinicaulis) Roots Cuticle and daily Solar Radiation. World Journal of Pharmaceutical Research. Oct 2021; 10(12): 2503-14.

[36] Liao BH. Relations between biomass of (Smilax scobinicaulis) Fresh Roots and Daily Solar Radiation. International Journal of Science and Research Archive. Nov 2021; 4(1): 18-25.

[37] Liao BH. Interrelations of Biomass of (Smilax scobinicaulis) Stems Cuticle and Dalily Solar Radiation along Different Elevation Environmental Gradient. European Journal of Biomedical and Pharmaceutical sciences. Oct 2021; 8(11): 42-48.

[38] Zhu DM, Liao BH. A dynamical system of human cognitive linguistic theory in learning and teaching of the typical university in Henan Province. International Journal of Pharmacy \& Therapeutics. Jan 2015; 6(1): 4-6. 
[39] Wang XM, Liao BH, Zhang JM. Distribution of pharmacognosy plant species by the correlating to numbers of tourists in Qi-Cheng park of China. International Journal of Ecology and Environmental Sciences. Oct 2020; 2(4): 152-55.

[40] Chen HS, Liao BH, Huang CZ, Zhao GQ, Chen SP, Li YJ, Liu DD, Huang F, Guo PS, Wu NN, Geng QL, Li YZ, Yan GJ. Research on risk assessment and early warning mechanism of agriculture non-point source pollution in Bai-gui Lake watershed by GIS. International Journal of Pharmacognosy and Pharmaceutical Sciences. 2019 Jan; 1(1): 25-29.

[41] Shen YS, Liao BH. Study on the treatment of Acid Red 4 wastewaters by a laminar-falling- film-slurry-type VUV photolytic process. Water Science and Technology. Nov 2007; 55(12): 13-18.

[42] GBIF (Free and access to biodiversity).

[43] Ding BZ, Wang SY, et al. Plants flora in Henan Province. Henan People's Press. (1981, 1988, 1997 and 1998).

[44] Markham J, Fernández OM. Bryophyte and lichen biomass and nitrogen fixation in a high elevation cloud forest in Cerro de La Muerte, Costa Rica. Oecologia. Feb 2021; 195(2): 489-97.

[45] Kueppers LM, Southon J, Baer P, Harte J. Dead wood biomass and turnover time, measured by radiocarbon, along a subalpine elevation gradient. Oecologia. Dec 2004; 141(4): 641-51.

[46] Alday JG, Martínez de Aragón J, de-Miguel S, Bonet JA. Mushroom biomass and diversity are driven by different spatiotemporal scales along Mediterranean elevation gradients. Scientific Reports. 6 Apr 2017; 7: 45824.

[47] Carlyle CN, Fraser LH, Turkington R. Response of grassland biomass production to simulated climate change and clipping along an elevation gradient. Oecologia. Mar 2014; 174 (3): 1065-73.

[48] Kopeć W, Telenius J, Khandelia H. Molecular dynamics simulations of the interactions of medicinal plant extracts and drugs with lipid bilayer membranes. The FEBS Jounal. Jun 2013; 280(12): 2785-805.

[49] Shidhi PR, Nadiya F, Biju VC, Vijayan S, Sasi A, Vipin CL, Janardhanan A, Aswathy S, Rajan VS, Nair AS. Complete chloroplast genome of the medicinal plant Evolvulus alsinoides: comparative analysis, identification of mutational hotspots and evolutionary dynamics with species of Solanales. Physiology and Molecular Biology of Plants. Aug 2021; 27(8): 1867-84

[50] Kunwar RM, Acharya RP, Chowdhary CL, Bussmann RW. Medicinal plant dynamics in indigenous medicines in farwest Nepal. Jounal of Ethnopharmacology. Apr 2015; 163: 210-19.

[51] Papageorgiou D, Bebeli PJ, Panitsa M, Schunko C. Local knowledge about sustainable harvesting and availability of wild medicinal plant species in Lemnos island, Greece. Journal of Ethnobiology and Ethnomedicine. Jun 2020; 16(1): 36.

[52] Das K, Dang R, Shivananda TN, Sur P. Interaction between phosphorus and zinc on the biomass yield and yield attributes of the medicinal plant stevia (Stevia rebaudiana). Scientific World Journal. May 2005; 5: 390-95.

[53] Elkins AC, Deseo MA, Rochfort S, Ezernieks V, Spangenberg G. Development of a validated method for the qualitative and quantitative analysis of cannabinoids in plant biomass and medicinal cannabis resin extracts obtained by super-critical fluid extraction. Journal of Chromatogr B., Analytical Technologies in the Biomedical and Life Sciences. Mar 2019; 1109: 76-83.

[54] Fraser LH, Pither J, Jentsch A, Sternberg M, Zobel M, Askarizadeh D, Bartha S, Beierkuhnlein C, Bennett JA, Bittel A, Boldgiv B, Boldrini II, Bork E, Brown L, Cabido M, Cahill J, Carlyle CN, Campetella G, Chelli S, Cohen O, Csergo AM, Díaz S, Enrico L, Ensing D, Fidelis A, Fridley JD, Foster B, Garris H, Goheen JR, Henry HA, Hohn M, Jouri MH, Klironomos J, Koorem K, Lawrence-Lodge R, Long R, Manning P, Mitchell R, Moora M, Müller SC, Nabinger C, Naseri K, Overbeck GE, Palmer TM, Parsons S, Pesek M, Pillar VD, Pringle RM, Roccaforte K, Schmidt A, Shang Z, Stahlmann R, Stotz GC, Sugiyama S, Szentes S, Thompson D, Tungalag R, Undrakhbold S, van Rooyen M, Wellstein C, Wilson JB, Zupo T. Worldwide evidence of a unimodal relationship between productivity and plant species richness. Science. Jul 2015; 349(6245): 302-5.

[55] Liao BH, Zhang JM. Research on eco-restoration of damaged agro-ecosystem by new biodiversity technology. International Journal of Scientific Research Updates. Nov 2021; 2(1): 10-16. 